\title{
Injektabel Komposit Hydroksiapatit-Gelatin sebagai Sistem Penghantaran Alendronat
}

Aniek Setiya Budiatin*, Junaidi Khotib, Didik Hasmono, Samirah

Clinical Pharmacy Department, Faculty of Pharmacy Universitas Airlangga

*Corresponding author: anieksb@yahoo.co.id

\begin{abstract}
Background: Bisphosphonates, such as alendronate (ALE), have been known to be effective in the treatment of bone cancer and osteoporosis. However, it has been reported that the systemic administration of ALE causes a considerable side effect. Thus, the formulation injectable bone substitute (IBS) for local administration of ALE, which functions as drug delivery system (DDS) as well as filling agent in osteoporosis-induced bone fracture, is needed. Objective: To establish the biodegradable and biocompatible formulation for ALE in injectable form which supports the drug delivery system and acts as filling agent in bone fracture. Methods: Hydroxyapatite (HA) was added to the mixture of gelatin and hydroxypropyl methyl cellulose (GEL-HPMC). ALE was added to the mixture and semisolid form was prepared for granulation. The dried granule, as injectable matrix, was grinded and mixed with appropriate amount of $\mathrm{Na}_{2} \mathrm{HPO}_{4}$. Results: Porosity of injectable form was higher than those of granule form. Injectable semisolid form was produced by adding $0.8 \mathrm{~mL} \mathrm{Na} \mathrm{HPO}_{4}$ on each gram of granule with 10-12 min setting time. MTT assay showed that matrix was biocompatible showed by more than 100\% viability. In vitro dissolution study showed that ALE was slowly released in more than 20 days. Conclusions: The formula of IBS using HA-GEL-HPMC may act as an effective drug delivery system for local administration of ALE in bone fracture.

Keywords: hydroxyapatite, gelatin, $\mathrm{HPMC}$, alendronat, $\mathrm{Na}_{2} \mathrm{HPO}_{4}, \mathrm{DDS}$ (Drug Delivery System)
\end{abstract}

\begin{abstract}
Abstrak
Latar belakang: Golongan bisfosfonat sebagai obat kelainan tulang sudah lama dipergunakan seperti kanker tulang dan osteoporis. Namun karena efek samping dari obat tersebut maka dibuat formula lokal dalam bentuk injektabel yang berfungsi sebagai sistem penghantaran obat dan pengisi celah yang terbentuk dari fraktur akibat osteoporosis. Tujuan: untuk membuat formula dari hidroksiapatit (HA) dan gelatin (GEL) sebagai penghantaran/pembawa obat (SPO) maupun pengisi tulang. Formula injektabel bersifat biodegradable dan biokompatibel dan obat yang digunakan adalah alendronat (ALE). Hidroksi propil Metil Selulosa (HPMC) ditambahkan untuk memudahkan pembawa membentuk bahan setengah padat. Metode: HA ditambahkan ke dalam campuran GEL-HPMC diaduk selajutnya di tambahkan ALE dan diaduk sampai membentuk massa yang tepat untuk dibuat granul. Granul kering digerus sebagai matrik injektabel dan diencerkan dengan Na2HPO4. Hasil: porositas (SEM) bentuk granul < bentuk hasil injeksi, repasta dari matrik bentuk serbuk memerlukan $\mathrm{Na}_{2} \mathrm{HPO}_{4} 0,8 \mathrm{ml} / \mathrm{gram}$ dan seting dalam waktu 1012 menit. Matrik bersifat biokompatibel dengan viabilitas $>100 \%$ (MTT). Dari hasil uji disolusi in vitro menunjukkan bahwa ALE dapat dilepas secara perlahan dalam waktu $>20$ hari. Kesimpulan: Formula injektabel (IBS) HA-GEL-HPMC dapat berfungsi sebagai penghantaran ALE secara lokal.
\end{abstract}

Kata kunci: hidroksi apatit, Gelatin, $\mathrm{HPMC}$, alendronat, $\mathrm{Na}_{2} \mathrm{HPO}_{4}$, sistem penghantaran obat

\section{PENDAHULUAN}

Komposit seramik dan scaffold merupakan material implan yang popular untuk gigi, orthopedik dan bedah plastik. Salah satu contoh seramik yang sering digunakan adalah hidroksiapatit (HA) sebagai bahan dasar dari rekayasa tulang. Bovine hydroxyapatite (BHA), merupakan seramik yang sangat sesuai sebagai matriks implan karena sifatnya mirip HA tulang manusia. Sebagai scaffold BHA bersifat biokompatibel karena memiliki sifat osteokonduktif yang tinggi bila dibanding HA sintesis (Aniek et al., 2014). Untuk memperbaiki sifat mekanik dan fisik BHA dikombinasi dengan gelatin (GEL) yang bersifat plastis, biodegradabel, biokompatibel. Komposit HA-GEL cocok digunakan sebagai material pengganti tulang dengan tingkat biokompatibilitas yang tinggi serta tidak toksik setelah diuji secara in vitro selama 24 jam dengan komposisi 50\% w/w hidroksiapatit (Askarzadeh, 2004). Azami (2012) juga telah melakukan penelitian bahwa komposisi HA-GEL yang dapat digunakan adalah 40:60. Adanya penambahan gelatin bertujuan 
meningkatkan adhesi osteoblast, migrasi dan mineralisasi. Selain itu, komposit HA-GEL memenuhi hampir semua sifat yang disyaratkan oleh bone substitute, sesuai hasil uji in vitro, in vivo, fisis dan kimiawi (Azami et al., 2012, Aniek et al.,2014).

Pemberian secara lokal Alendronat dalam bentuk injectable bone subtitute (IBS) dari formula BHAGEL-ALE diharapkan dapat meningkatkan efektivitas alendronat untuk menghambat aktivitas osteoklas dalam progresivitas osteoporosis sedangkan BHA-GEL dapat berfungsi sebagai pengisi tulang (Aniek et al., 2014). Penambahan HPMC dalam formula ini untuk mempermudah pembasahan serbuk membentuk masa injektabel setengah padat sehingga mudah mengalir masuk ke dalam celah-celah tulang yang porus sebagai pengisi tulang. Dalam penelitian ini dilakukan pembuatan formula injektabel dengan komposisi BHA: GEL $(20 \%)=5: 1$ sebagai pembawa ALE 10\% dan HPMC 2\% sebagai suspending agent serta $\mathrm{Na}_{2} \mathrm{HPO}_{4}$ untuk mempercepat setting dari formula.Selanjutnya dilakukan evaluasi karakteristik fisikokimia dari formula antara lain setting time, SEM dan disolusi formula.

\section{BAHAN DAN METODE}

\section{Bahan}

Bahan-bahan yang digunakan yaitu bubuk hidroksiapatit tulang sapi (BHA) dari Bank Jaringan RSUD Dr. Soetomo Surabaya, Gelatin (150 bloom) kulit sapi didapatkan dari Rousselot (Guangdong, China), Alendronat didapatkan dari Hetero Labs (India), Hydroxypropylmethylcellulose (HPMC) didapatkan dari Sigma Aldrich H7509, bahan-bahan pembuat buffer fosfat yaitu $\mathrm{NaCl}, \mathrm{Na}_{2} \mathrm{HPO}_{4}$, $\mathrm{NaH}_{2} \mathrm{PO}_{4}$ (Sigma Aldrich), Aquades, Aquabides.

\section{Preparasi pembuatan sampel injektabel}

HPMC 2\% (w/v) dibuat dengan cara HPMC dimasukkan ke dalam aquades bersuhu $90-100^{\circ} \mathrm{C}$, masukkan GEL 20\% (w/v) diaduk terus hingga suhu aquades $40^{\circ} \mathrm{C}$. Perbandingan BHA dan Gelatin (GEL) adalah 5 : 1 (kering), lalu ditambahkan ALE $10 \%$ selanjutnya diaduk hingga homogen. Larutan HPMC-GEL ditambahkan pada campuran BHA-ALE sedikit demi sedikit dan diaduk terus sampai homogen dan membentuk formula kalis. Selanjutnya dicetak menjadi granul dengan mes berukuran 1,0 $\mathrm{mm}$, dikeringkan dalam oven $40^{\circ} \mathrm{C}$ selama 24 jam. Untuk membentuk injectable bone substitute (IBS), granul yang sudah kering digerus ulang menjadi serbuk, selanjutnya ditambahkan larutan $\mathrm{Na}_{2} \mathrm{HPO}_{4}$ $2,5 \%$.

\section{Kharakterisasi Fisikokimia}

Setting time. Proses pengujian dilakukan dengan cara menambahkan $\mathrm{Na}_{2} \mathrm{HPO}_{4} 2,5 \%$ pada 1,0 gram IBS sampai membentuk kondisi setengah padat hingga dapat diinjeksikan melalui spuit injeksi. Volume $\mathrm{Na}_{2} \mathrm{HPO}_{4} 2,5 \%$ yang ditambahkan dan waktu setting dicatat.

Uji SEM digunakan untuk melihat morfologi permukaan BHA-GEL-HPMC-ALE bentuk granul, hasil injeksi yang sudah setting sehingga dapat diketahui ukuran pori pori yang terbentuk sebelum dan setelah adanya proses perendaman. The sample coated with carbon tip to examination.

Uji kuantitatif kadar alendronate. Ditimbang serbuk formula injektabel 1 gram, selanjutnya dimasukkan dalam Erlenmeyer $100 \mathrm{ml}$. Ditambahkan aquades $10 \mathrm{ml}$ divortek selama 10 menit, tuang ke dalam labu ukur $100 \mathrm{ml}$ dan tambahkan campuran $\mathrm{CUSO}_{4} .5 \mathrm{H}_{2} \mathrm{O}$ dan $\mathrm{HNO}_{3} 0,1 \mathrm{~N}$, amati secara spektrofotometri (Koba et al.,2008)

\section{Uji toksisitas}

Sel yang digunakan dalam penelitian ini adalah fibroblast BHK-21 (Baby Hamster Kidney-21) karena sel tersebut memiliki kecepatan pertumbuhan tinggi dan kemampuan memperbanyak diri serta integritas sel tetap terjaga. Setelah proses inkubasi selama 24 jam dilakukan pengamatan dengan Reader Elisa, menghasilkan nilai Optical Density (OD) dan berdasarkan nilai tersebut diperoleh nilai Viabilitas/pertumbuhan sel dihitung dengan persamaan sebagai berikut:

Viabilitas Sel $(\%)=\frac{\text { OD Perlakuan + OD Kontrol Media }}{\text { OD Kontrol Sel + OD Kontrol Media }} \times 100 \%$

\section{Disolusi Obat.}

Formula injectabel yang sudah setting/ kering direndam dalam aquades sekitar $2 \mathrm{ml}$. Cuplikan aquades sebanyak $0,5 \mathrm{ml}$ diambil setiap 24 jam 
hingga hari ke-21 untuk mengetahui banyaknya alendronat yang terlepas < dilakukan penggantian aquades $0,5 \mathrm{ml}$ dari setiap pengambilan. Hasil cuplikan disimpan dalam freezer pada suhu $-40^{\circ} \mathrm{C}$ sampai dilakukan analisis (Aniek et al., 2014).

\section{HASIL DAN PEMBAHASAN}

Formula yang diperoleh adalah BHA:GEL:HPMC yaitu 5:1:1 (kering) dan ALE 10\%. Setting time secara in vitro dilakukan pengamatan waktu formula mengeras setelah keluar dari spuit injeksi telihat seperti Tabel 1.

Tabel 1. Volume cairan dan Setting Time

\begin{tabular}{|c|c|c|c|c|}
\hline No & $\begin{array}{c}\text { Berat } \\
\text { formula } \\
(\mathrm{g})\end{array}$ & $\begin{array}{c}\text { Larutan } \\
\mathrm{Na}_{2} \mathrm{HPO}_{4} \\
2,5 \%(\mathrm{ml})\end{array}$ & Hasil & $\begin{array}{c}\text { Setting } \\
\text { Time } \\
(\mathrm{menit})\end{array}$ \\
\hline 1 & 1,0070 & 1,0 & $\begin{array}{c}\text { Hampir } \\
\text { Cair }\end{array}$ & 30 menit \\
\hline 2 & 1,0042 & 0,9 & Lembek & 15 menit \\
\hline 3 & 1,0100 & 0,8 & Lembek & $\begin{array}{c}10-12 \\
\text { menit }\end{array}$ \\
\hline 4 & 1,0006 & 0,5 & $\begin{array}{c}\text { Cepat } \\
\text { kering }\end{array}$ & $2-3$ menit \\
\hline
\end{tabular}

Besar porositas sediaan menentukan kecepatan difusi cairan ke dalam sediaan dan pelepasan obat. Makin besar porositas, volume cairan yang berdifusi ke dalam matrik akan meningkat dan obat yang terikat matrik semakin cepat terlepas (Gambar 1)

Setting time dilakukan untuk mengetahui waktu yang dibutuhkan komposit BHA-GEL-HPMC dengan penambahan alendronat mengalami proses setting saat aplikasi sebagai injectable bone substitute (IBS). Formula injektabel selanjutnya disebut IBS berbentuk setengah padat sehingga mudah mengalir dari spuit injeksi untuk mengisi celah tulang akibat fraktur osteoporosis.

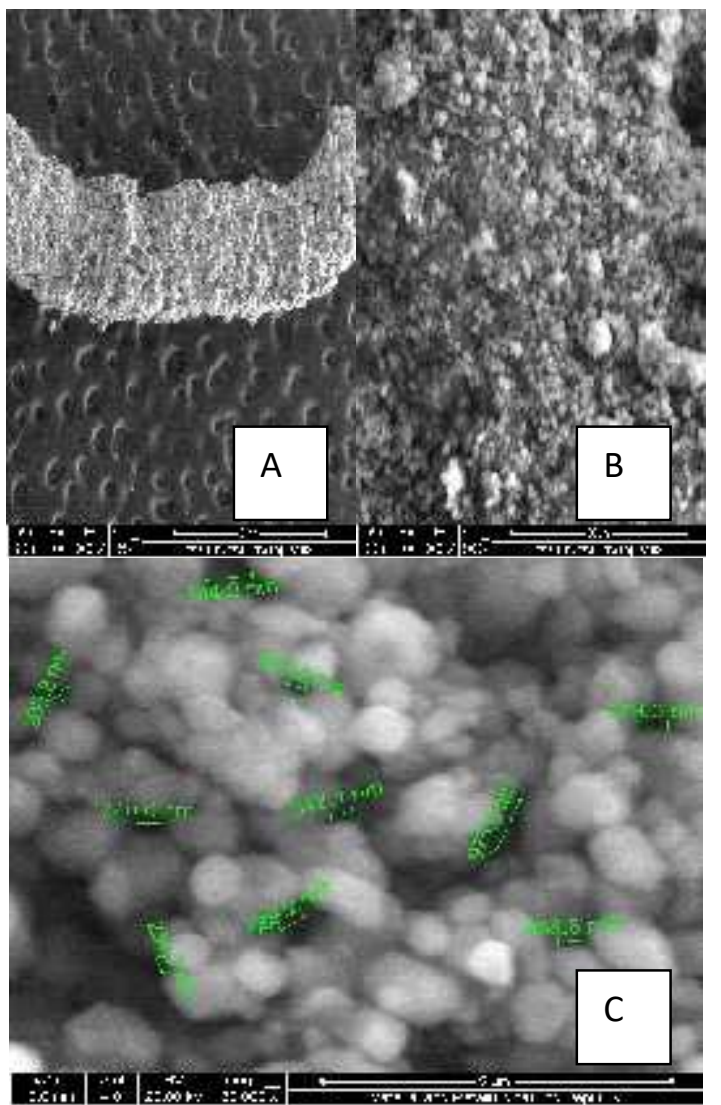

Gambar 1. Sampel Bentuk Granul (A); Struktur permukaan sampel dengan perbesaran $5.000 \mathrm{X}$ dengan range $10 \mu \mathrm{m}(\mathrm{B})$; Perbesaran 30.000X dengan range $5 \mu \mathrm{m}(\mathrm{C})$, angka-angka menunjukkan porositas dari sampel

Penambahan $\mathrm{Na}_{2} \mathrm{HPO}_{4}, \quad 2,5 \%$ ditambahkan sebagai pengencer dan juga sebagai larutan yang mempercepat setting time. Hasil penelitian (Tabel 1) menunjukkan formula yang baik adalah IBS dengan $0,9 \mathrm{ml} \mathrm{Na} 2 \mathrm{HPO}_{4}, 2,5 \%$ memerlukan waktu 15 menit untuk setting, waktu tersebut cukup untuk persiapan injeksi formula pada celah dan penutupan dari bagian yang diinsisi.

Porositas yang tinggi menyebabkan cairan mudah masuk ke dalam formula (Gambar 1 dan Gambar 2). Ukuran pori pori dari granul lebih kecil dibanding hasil injektabel hal ini disebabkan kerena kandungan air yang berbeda saat pembuatan dan tekanan saat pencetakan formula. Porositas dari hasil IBS yang lebih besar sebagai scaffold memudahkan sel sel sekitarnya untuk migrasi, proliferasi dan diferensiasi di dalamnya. Formula IBS yang mengandung alendronat bersifat tidak toksik/ aman terhadap sel di sekelilingnya terlihat dari hasi uji 
MTT \{3-(4,5-dimetil-2-thiazolil)-2,5-diphenil-2tetrazoliumbromida Sistem pembawa obat (DDS) yaitu BHA-GEL maupun BHA-GEL-HPMC menunjukkan prosen pertumbuhan sel fibroblast BHK-21(Baby Hamster Kidney) lebih dari 100\%, hal ini berarti bahwa bahan tersebut bersifat biokompatibel terhadap lingkungan (Aniek et al.,2014).

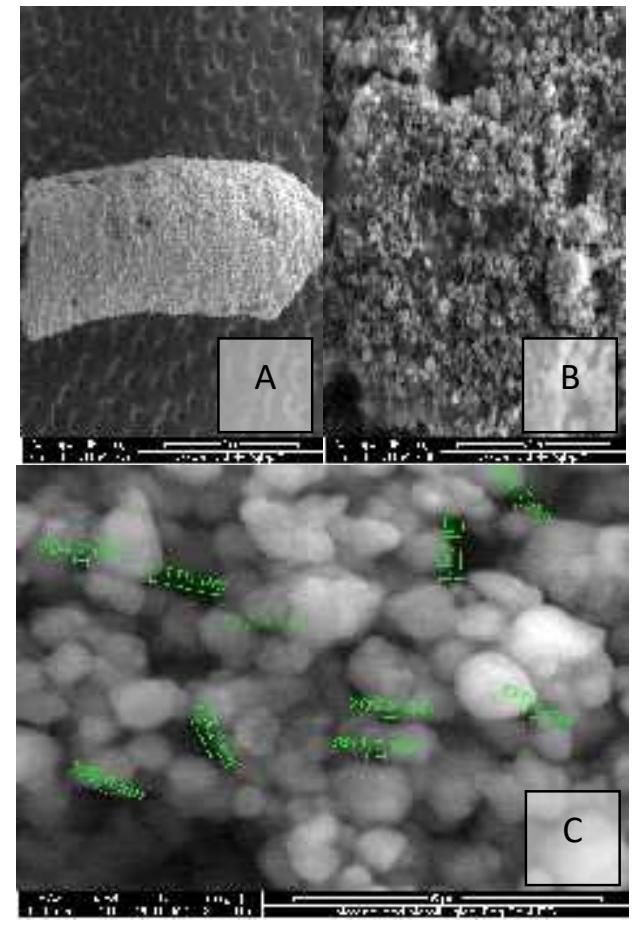

Gambar 2. Sampel setelah keluar dari spuit injeksi dan mengering (A); Struktur permukaan sampel dengan perbesaran $5.000 \mathrm{X}$ dari range $10 \mu \mathrm{m}(\mathrm{B})$; Perbesaran 30.000X dengan range $5 \mu \mathrm{m}(\mathrm{C})$, angkaangka menunjukkan porositas dari sampel

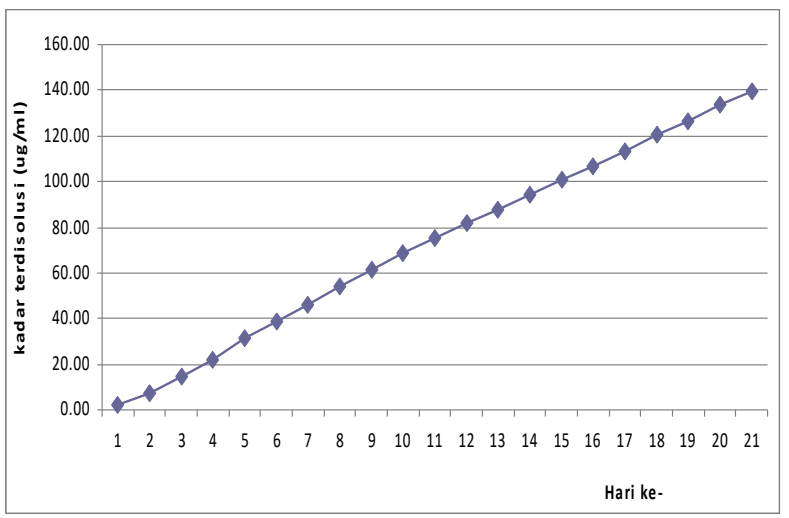

Gambar 3. Profil pelepasan ALE dari formula BHAGEL-ALE-HPMC, bentuk granul
Sedangkan viabilitas bahan aktif Alendronat juga bersifat biokompatibel yang menunjukkan pertumbuhan $>60 \%$. Apabila pertumbuhan sel $>$ $60 \%$ maka dinyatakan bahwa formula bersifat aman terhadap sel disekelilingnya (Spielmann et al., 2006). Formula BHA-GEL-HPMC-ALE bersifat biokompatibel dan biodegradabel, hasil degradasi dari formula dapat bersatu dan meningkatkan proliferasi sel di sekitarnya.

Uji disolusi obat menunjukkan bahwa alendronat dapat dihantarkan oleh injectable bone substitute (IBS) dalam waktu yang ditentukan. Alendronat (ALE) yang terlepas pada hari pertama menunjukkan bahwa ALE yang teradsorpsi dipermukaan akan segera terlepas saat bersinggungan dengan fase cair. Pelepasan selanjutnya menurun, hal ini disebabkan adanya proses difusi cairan masuk ke dalam formula untuk melarutkan ALE yang posisinya terikat/ terdistribusi lebih dalam. Besarnya ALE yang terlepas sesuai dengan kecepatan difusi cairan, kelarutan ALE dalam pelarut dan difusi ALE ke luar dari formula serta kekuatan GEL untuk mengembang, selanjutnya formula akan mengalami erosi. Gelatin (GEL) mempunyai kekuatan untuk menyerap cairan sebanyak 10 kali beratnya (Hilliq et al., 2008), selanjutnya GEL akan mengembang dan terdegradasi. BHA merupakan garam kalsium fosfat, ALE akan terikat kuat oleh atom kalsium dalam jumlah terbatas, dengan penambahan GEL maka ALE yang dapat ditambahkan dalam formula dapat mencapai 10\% (Panzavolta et al., 2010). Penambahan HPMC akan mempercepat degradasi dari formula, karena sifatnya yang hidrofil sangat mudah menyerap cairan di sekelilingnya. Karena dalam formula ini bahan-bahan yang digunakan bersifat biokompatibel maka hasil degradasi akan bersatu dengan sel-sel disekitarnya untuk regenerasi sel. Sehingga dari uji disolusi menunjukkan ALE dapat dilepas secara bertahap dalam waktu lama. Hasil uji yang diperoleh selama 21 hari sampling digambarkan (Gambar 4) dalam grafik waktu vs jumlah ALE yang terlepas dari Sistem Penghantaran Obat menghasilkan persamaan regresi $\mathrm{Y}=0,1299 \mathrm{X}+0,3733$ dan $\mathrm{R}^{2}=$ 0,8146 . 


\section{KESIMPULAN}

Formula injektabel (IBS) dengan komposisi BHAGEL-HPMC dapat digunakan sebagai Sistem penhantaran obat dari alendronat.

\section{UCAPAN TERIMAKASIH:}

Prof Dr M Zainuddin atas segala bimbingan dan pemberi semangat serta Dr Ferdiansyah, dr.,Sp.OT (K) atas bimbingan dan pemberian BHA.

\section{DAFTAR PUSTAKA}

Aniek SB, M.Zainuddin, Junaidi Khotib. 2014. Biocompatable Composite As Gentamicin Delivery System for Osteomyelitis and Bone Regeneration, International Journal of Pharmacy and Pharmaceutical Sciencis. Vol 6, Issue 3, p.223-226

Askarzadeh, K., Orang, F., and Moztarzadeh, F., 2004, Fabrication and Characterization of a Porous Composite Scaffold Based on Gelatin and Hydroxyapatite for Bone Tissue Engineering, Iranian Polymer Journal 14 (6), Tehran, Iran: 511-520.

Azami, M., Tavakol, S., Samadikuchaksaraei, A., Hashjin, M. S., Baheiraei, N., Kamali, M., dan Nourani, M. R., 2012, A Porous Hydroxyapatite/Gelatin Nanocomposite Scaffold for Bone Tissue Repair: In Vitro and In Vivo Evaluation, Journal of Biomaterials Science, Tehran, Iran: 1-16.

Bohner, M., 2010, Design Of Ceramic-Based Cements and Putties for Bone Graft Substitution, Woodhead Publishing Limited: Injectable Biomaterial, Switzerland: 1-12.

Catterall, J. B. and Cawston, T. E., 2002, Drugs in Development: Bisphosphonate and Metalloproteinase Inhibitors, Arthritis Research and Therapy Vol. 5 No. 1, Newcastle, United Kingdom: 12-24.

Ferraz, M. P., Moteiro F. J. and Manuel, C. M., 2004, Hydroxyapatite Nanoparticles: A Review Preparation Methodologies, Journal of Applied Biomaterials and Mechanics 2004, 2, Portugal: 74-80.

Hajrawati, 2006, Sifat Fisik dan Kimia Gelatin Tulang Sapi dengan Perendaman Asam Klorida pada Konsentrasi dan Lama Perendaman yang Berbeda, Tesis, Sekolah Pascasarjana Institut Pertanian Bogor, Bogor.

Kim, H. W., Knowles, J. C. and Kim, H. E., 2004, Hydroxyapatite and Gelatin Composite Foam Process via Novel Freeze-Drying and Crosslinking for Use as Temporary Hard Tissue
Scaffolds, Wiley Interscience, Seoul, South Korea: 136-145.

Koba M, Koba K and Przyborowski. 2008. Aplication of Uv-Derivative Spectrophotometry For Determination of Some Bisphosphonates Drugs In Pharmaceutical Formulations, Acta Poloniae Pharmaceutica-Drug Research, Vol 65 No 3 pp 289-294.

Lui, P.P.Y., Lee, Y. W., Mok, T. Y., Cheuk, Y. C., and Chan, K. M., 2013, Alendronate Reduce Peri-Tunnel Bone Loss and Enhanced Tendon Graft to Bone TunnelHealing in Anterior Cruciatum Ligament Reconstruction, European Cells and Materials Vol. 25 (2013), Hongkong: 78-96.

Park, J., 2008, Bioceramics: Properties, Characterization and Applications, Springer Business uand Media, Iowa, USA.

Ratner, B. D., Hoffman, A. S., Schoen, F. J. and Lemons, J. E., 2004, Biomaterial Science: An Introduction to Materials in Medicine, Second Edition, Elsevier Academic Press, San Diego, USA.

Spielmann Horst, Andrea Seiler, Susanne Bremer, Laras Hareng, Thomas Hartung, Hans Ahr, Elaine Faustmen, Ulla Hass. 2006. The Application of Three Validated in Vitro Embryotoxicity Test. ATLA 34, 527-538.

Warastuti, Y. dan Abbas, B., 2011, Sintesis dan Karakterisasi Pasta Injectable Bone Substitute Iradiasi Berbasis Hidroksiapatit, Jurnal Ilmiah Aplikasi Isotop dan Radiasi, Jakarta: 73-93.

Weiss, P., Gauthier, O., Bouler, J. M., Grimandi, G. and Daculsi, G. 2007. Injectable Bone Substitute Using a Hydrophilic Polymer. Equipe INSERM Materiaux V. 1., France: 1-8 